\title{
Sosok Guru Profesional yang Ideal Ala Ki Hajar Dewantara
}

\author{
Mohammad Tohir \\ Mahasiswa S2 Pendidikan Matematika FKIP Universitas Jember \\ Guru SMP Negeri 2 Jember \\ Email: 160220101001@students.unej.ac.id
}

Disetiap tanggal 2 Mei Masyarakat Indionesia selalu memperingati Hari Pendidikan Nasional (Hardiknas). Hal ini bertepatan dengan hari ulang tahun Sang Guru Kita, yaitu Ki Hadjar Dewantara. Beliau merupakan salah satu Pahlawan Nasional di Indonesia yang dikenal dengan sebutan Bapak Pendidikan Nasional. Semboyan Sang Guru yang sangat poluler di kalangan masyarakat adalah Ing Ngarso Sung Tulodo, Ing Madyo Mangun Karso, Tut Wuri Handayani. Semboyan ini memiliki arti bahwa setiap diri kita harus memiliki ketiga sifat tersebut agar dapat menjadi insan yang berkarakter. Untuk mengenang jasa beliau, maka Peringatan Hari Pendidikan Nasional pada setiap tanggal 2 Mei tidak bisa dipisahkan dari sosok seorang Ki Hadjar Dewantara, tokoh yang berjasa memajukan pendidikan di Indonesia.

Ada lima point penting yang dapat Penulis temukan dari Sosok Ki Hajar Dewantara untuk menjadi guru profesional yang ideal, berikut lima point penting tersebut:

\section{Ki Hajar Dewantara Berani Melakukan Perubahan}

Ki Hadjar Dewantara dilahirkan pada tanggal 2 Mei 1889 di Yogyakarta dengan nama Raden Mas Suwardi Suryaningrat. Ayahnya seorang pangeran yand bernama Pangeran Suryaningrat yang merupakan putra Paku Alam ke-4 dari Yogyakarta. Beliau menamatkan pendidika dasar di ELS (Sekolah Dasar Eropa/Belanda). Kemudian ia bekerja sebagai penulis dan wartawan di beberapa surat kabar, antara lain, Sediotomo, Midden Java, De Expres, Oetoesan Hindia, Kaoem Moeda, Tjahaj Timoer, dan Poesara. Pada masanya, ia tergolong penulis handal. Tulisan-tulisannya komunikatif dan tajam dengan semangat antikolonial.

Soewardi muda sangat ulet sebagai seorang wartawan muda, beliaunya juga aktif dalam organisasi sosial dan politik. Sejak berdirinya Boedi Oetomo (BO) tahun 1908, beliaunya aktif di seksi propaganda untuk menyosialisasikan dan menggugah kesadaran masyarakat Indonesia (terutama Jawa) pada waktu itu mengenai pentingnya persatuan dan kesatuan dalam berbangsa dan bernegara. Kongres pertama BO di Yogyakarta juga diorganisasi olehnya. beliaunya juga menjadi anggota organisasi Insulinde, suatu organisasi multietnik yang didominasi kaum Indo yang memperjuangkan pemerintahan sendiri di Hindia Belanda, atas pengaruh Ernest Douwes Dekker (DD). Ketika kemudian DD mendirikan Indische Partij, Soewardi diajaknya pula.

Selama di Belanda Soewardi muda memanfaatkan kesempatan ini untuk mendalami masalah pendidikan dan pengajaran. Setelah Soewardi muda kembali ke Indonesia pada bulan September 1919. Segera kemudian ia bergabung dalam sekolah binaan saudaranya. Pengalaman mengajar ini kemudian digunakannya untuk mengembangkan konsep mengajar bagi sekolah yang ia dirikan pada tanggal 3 Juli 1922: Nationaal Onderwijs Instituut Tamansiswa atau Perguruan Nasional Tamansiswa. Saat ia genap berusia 40 tahun menurut hitungan penanggalan jawa, ia mengganti namanya menjadi Ki Hadjar Dewantara. Ia tidak lagi menggunakan gelar kebangsawanan di depan namanya. Hal ini dimaksudkan supaya ia dapat bebas dekat dengan rakyat, baik secara fisik maupun jiwa. Kemudian beliau memusatkan perjuangan melalui pendidikan dengan mendirikan perguruan Taman Siswa pada tanggal $3 \mathrm{JuIi}$ 1922. Perguruan ini merupakan wadah untuk menanamkan rasa kebangsaaan kepada anak didik. Ajaran Ki Hajar Dewantara yang terkenal adalah ing ngarsa sung tulodo, ing madya mangun karsa, dan tut wuri handayani. Artinya adalah di depan memberi teladan, di tengah memberi semangat, dan di belakang memberi dorongan. 


\section{Ki Hajar Dewantara Penggerak dan Pendidik}

Beberapa tokoh pergerakan yang yang ada di Indonesia merupakan sosok insan yang konsisten, terpelajar, radikal, dan pandai bersiasat dalam memperjuangkan kemerdekaan Indonesia. Akan tetapi, tidak banyak yang meninggalkan lembaga yang didirikan sejak zaman penjajahan Kolonial Belanda dan bertahan hingga sekarang serta nama dan waktu lahirnya diperingati oleh jutaan penduduk Indonesia kontemporer. Diantara tokoh penggerak masuk di dalamnya akan tetapi tidak ada jejak lembaga yang telah didirikan dan bertahan hingga sekarang. Hanya jejak lembaga pendidikan yang telah didirikan oleh Ki Hadjar Dewantara hingga saat ini bertahan.

Sejarah Indonesia telah mencatat bahwa Ki Hadjar Dewantara bukan saja merupakan salah satu perintis dunia pendidikan di Indonesia, melainkan juga salah satu perintis dunia jurnalistik Indonesia. Di masa mudanya, beliau menjadi aktivis organisasi Insulinde, Sjarekat Islam, Boedi Oetomo, Indische Partij, serta politisi dan pendiri Pergoeroean Nasional Tamansiswa. Ki Hadjar Dewantara kemudian dianugrahi Pahlawan Nasional, Bapak Pendidikan Indonesia, sekaligus mendapat gelar kehormatan yakni doktor honoriscausa dari Universitas Gadjah Mada. Berdasarkan Surat Keputusan Presiden RI No. 305 Tahun 1959 Tanggal 28 November 1959, hari lahir beliau telah ditetapkan sebagai Hari Pendidikan Nasional. Semboyan beliau, tutwuri handayani, sampai saat ini menjadi slogan Kementrian Pendidikan Nasional dan tercantum dalam lambang pendidikan Indonesia.

Sedangkan mengenai sosok guru, Ki Hajar Dewantara telah mengisyaratkan posisinya itu dengan melalui petuah-petuah dalam bahasa sansekerta. Guru bukan sekedar mengajarkan keilmuan tertentu, tapi dia juga harus dapat menjadi instrument perekat nilai-nilai kebangsaan, nasionalisme, cinta tanah air, nilai religiusitas dan spritualitas. Selain itu juga guru harus menjadi tauladan bagi siswa, menjadi orang tua yang selalu membimbing anaknya, menjadi problem solver dalam setiap sumbatan pengetahuan dan wacana bagi orang-orang di sekitanya. Nilai esensial yang harus tertanam pada seorang guru sebagai sokoguru pendidikan di Indonesia adalah berfikir, berdzikir, beramal sholeh, serta mengabdi kepada masyarakat.

\section{Ki Hajar Dewantara Rendah Hati}

Ki Hadjar Dewantara menerapkan pendidikan yang humanis yaitu memanusiakan manusia yang berbudaya dan berkembang secara kognitif (daya cipta), afektif (daya rasa), dan konatif ( daya karsa). Dengan kata lain prinsip pendidikan Ki Hadjar Dewantara adalah "to educate the head, the heart, and the hand". Selain dari itu dalam ajaran Ki Hadjar Dewantara juga dikatakan bahwa guru hendaknya mempunyai ketauladan lebih dahulu, baru sebagai fasilitator dalam mengajar. Hal ini dapat kita mengerti dari arti nama Hajar Dewantara yang mempunyai arti guru yang mengajarkan kebaikan, keluhuran, dan keutamaan.

\section{Ki Hajar Dewantara Bijaksana}

Semboyan Ki Hajar Dewantara yang sangat bengitu melekat di benak kita masing-masing adalah "Ing ngarsa sung tulodo, Ing madyo mangun karso, Tut wuri handayani". Apabila hakikat dari semboyan ini benar-benar di implementasikan dengan baik dan benar oleh diri kita, maka akan memberikan dampak positif bagi diri kita sendiri dan generasi bangsa yang akan datang.

Ing ngarso Sung Tulodo, ketika di depan memberi teladan. Hakikat dari semboyang yang pertama ini mengajak kepada guru, bahwa guru harus mampu memberikan contoh yang baik dan benar bagi siswanya, baik sikap, perbuatan maupun pola pikirnya. Apalagi seorang guru dalam kurikulum 2013 juga dituntut untuk membentuk siswa yang salah satu kompetensi intinya dapat Menghargai dan menghayati perilaku jujur, disiplin, tanggungjawab, peduli (toleransi, gotong royong), santun, percaya diri, dalam berinteraksi secara efektif dengan 
lingkungan sosial dan alam dalam jangkauan pergaulan dan keberadaannya. Oleh karena itu, apabila guru memberikan teladan yang baik dan benar, maka perilaku siswa akan menjadi baik juga, bahkan mereka bisa jadi lebih baik dari pada kita. Dengan kata lain, seorang guru merupakan public figure yang akan dijadikan panutan siswanya, maka guru harus memiliki akhlak yang luhur.

Ing Madyo Mangun Karso, ketika di tengah memberikan semangat. Hakikat dari semboyang yang kedua ini mengajak kepada para guru, bahwa para guru haruslah berada di antara siswanya, dengan kata lain guru juga sebagai teman bagi siswanya. Dengan demikian, para guru dengan leluasa membimbing dan memberikan inspirasi kepada anak didiknya. Sehingga tercipta suasana belajar yang kondusif dan nyaman bagi mereka.

Tut Wuri Handayani, ketika di belakang memberikan daya kekuatan. Hakikat dari semboyan yang ketiga ini mengajak kepada para guru untuk selalu memberikan arahan yang baik dan benar dalam kemajuan belajar siswanya. Oleh karena itu para guru dapat memotivasi anak didiknya untuk lebih giat dalam belajar. Dengan demikian, mereka merasa selalu diperhatikan dan selalu mendapat pikiran-pikiran positif dari diri gurunya. Sehingga mereka selalu memandang ke depan dan tidak terpaku pada kondisinya saat ini.

Ketiga semboyan ini saling berkaitan antara satu dengan lainnya. Sebagai contoh, seorang guru memiliki tanggung jawab untuk menanamkan nilai-nilai pada siswanya. Dalam hal ini guru tidak hanya begitu saja mendorong dan mengarahkan siswanya untuk mengikuti nilai-nilai tersebut, tetapi guru juga harus memberikan contoh bagaimana nilai-nilai tersebut tertanam di dalam dirinya. Selain memberi contoh, guru juga harus mengarahkan nilai-nilai tersebut di tengah-tengah siswa dan memberi motivasi mereka untuk bertindak agar sesuai dengan nilainilai tersebut.

Ada satu semboyan lagi yang sangat melekat pada diri kita, yaitu Asih, Asah dan Asuh. Asih adalah mengasihi anak secara psikis agar terbentuk karakter atau jiwa yang saling menyayangi terhadap sesama. Asah adalah menajamkan intelektual atau pola pikir anak agar menjadi manusia yang cerdas dan pintar secara intelektual. Asuh adalah pemeliharaan anak secara fisik agar sehat dan kuat jasmaninya.

\section{Ki Hajar Dewantara Dapat Menjadikan Suasana Belajar Seperti Taman Bermain}

Ki Hajar Dewantara dalam mendirikan Perguruan Taman Siswa mempunyai tujuan mulya yang ingin tercapai, yaitu untuk membentuk manusia yang merdeka, baik secara fisik, mental, maupun kerohanian. Sedangkan landasan filosofisnya adalah nasionalistik dan universalistik. Nasionalistik berdasarkan budaya nasional dan universalistik berdasarkan hukum alam. Sedangkan suasana dalam pendidikan yang diajarkan dalam ajaran Ki Hadjar Dewantara adalah suasana yang berprinsip pada kekeluargaan, kebaikan hati, empati, cinta kasih, dan penghargaan terhadap masing-masing anggotanya. Sedangkan metode yang terdapat dalam ajaran Ki hadjar Dewantara adalah metode among yaitu metode yang berdasarkan pada asah, asih, dan asuh (care, dedication, love).

Seorang guru yang hebat tentunya harus memiliki keunggulan tertentu, baik dalam mengajar maupun hubungan dengan peserta didik, dan anggota komunitas sekolah serta pihak lain seperti dengan orang tua dan komite. Seorang guru juga harus mempunyai sikap profesionalitas yang tinggi yaitu keinginan untuk memperbaiki diri dan mengikuti perkembangan zaman sehingga penting bagi seorang guru untuk membangun etos kerja yang positif, menjunjung tinggi pekerjaan, menjaga diri dalam melaksanakan pekerjaan dan keinginan untuk melayani masyarakat. Lebih jauh lagi, guru juga harus memperhatikan penampilannya baik secara fisik, intelektual, relasi sosial, kepribadian dan kerohanian sehingga dapat menjadi motivator bagi anak didiknya. 
Sebagai anak bangsa kita wajib memberi penghormatan atas jasa-jasanya yang telah diberikan kepada bangsa ini. Bentuk penghormatan yang baik adalah meneladani semangat hidupnya dan mengemban visi dan misi beliau di bidang pendidikan. Karena melalui lembaga pendidikan inilah kita membangun masa depan bangsa yang dicita-citakan. Perubahan bangsa ini ke arah yang lebih baik bermula dari lembaga pendidikan. Sangat tepat apabila dikatakan bahwa lembaga pendidikan menjadi wadah untuk perubahan dan guru sebagai agen perubahan.

\section{Kesimpulan}

Berdasarkan kelima hasil temuan penulis diatas dapat disimpulkan. Bahwa untuk menjadi sosok guru profesional yang ideal ala Ki Hajar Dewantara, maka guru harus selalu melakukan perubahan diri kepada yang lebih baik, guru harus menempatkan diri sebagai among atau pembimbing, penasehat, pendidik, pengajar, pemberi motivasi, rendah hati, penuntun, tegas dan terhormat. Disamping itu juga guru harus ikhlas dalam mendidik siswa dan mampu menguasai kompetensi keguruannya yaitu pedagogik, profesional, sosial dan kepribadian.

Dengan memperingati Hardiknas, semoga negara Indonesia yang kita cintai ini menjadi bangsa yang besar dan dapat disegani di kancah dunia. Hal ini sesuai dengan rencana besar pemerintah untuk menyiapkan generasi emas pada tahun 2045 nanti yang dimulai dengan adanya Kurikulum 2013. Pemerintah pernah mengungkapkan bahwa tahun ini dianggap sebagai masa 'menanam' generasi emas tersebut. "Dari 2012-2035 Indonesia mendapat bonus demografi, dimana jumlah penduduk usia produktif paling tinggi di antara usia anak-anak dan orang tua".

Apalagi rencana pemerintah ini pernah diungkapkan oleh Ki Hajar Dewantara "TANAH air kita meminta korban. Dari di sinilah kita, siap sedia memberi korban yang sesuci-sucinya... sungguh, korban dengan ragamu sendiri adalah korban yang paling ringan... memang awan tebal dan hitam menggantung di atas kita. Akan tetapi percayalah di baliknya masih ada matahari yang bersembunyi... kapan hujan turun dan udara menjadi bersih karenanya?". Oleh karena itu, semoga dengan peringatan Hardiknas ini dapat membantu untuk mewujudkan cita-cita Bangsa dan Negara, terutama dalam dunia pendidikan, yaitu dapat menumbuhkembangkan siswa yang berakhlak mulia dan sebagai guru, kita dapat menjadi guru yang benar-benar akhlas mendidik para siswa kita. Amien Yarobbal Alamien...

\section{"Selamat Hari Pendidikan Nasional, 2 Mei 2016"}

\section{Pustaka}

Tohir, Mohammad. 2016. Sosok Guru Profesional yang Ideal Ala Ki Hajar Dewantara. Tersedia Online: http://pasca.unej.ac.id/sosok-guru-profesional-yang-ideal-ala-ki-hajar-dewantara/ [02 Mei 2016] 